\title{
TITLE:
}

Justifying the constitutional regulation of political parties: a framework for analysis

\section{Gabriela Borz}

School of Government and Public Policy

University of Strathclyde

16 Richmond Street

Glasgow, UK

gabriela.borz@strath.ac.uk

Short Bio: Dr Gabriela Borz is a lecturer at the University of Strathclyde, Glasgow, United Kingdom. Her research focuses on comparative party organization, constitutionalism, political representation, European integration and voting behaviour.

\begin{abstract}
What are the main reasons behind the regulation of political parties by contemporary constitutional practices? This article presents a framework for analysis which identifies types of justifications and actors involved in the process of regulation and their further influence on the outcomes of constitutionalization. The empirical focus is on the revelatory case of Luxembourg, which amended the constitution for the sole reason of giving parties constitutional status. The analysis suggests that the constitutional regulation of political parties depends on their current interests and power status. Additionally, the paper draws attention to the involvement of external actors and nevertheless to the changing nature of contemporary constitutionalism.
\end{abstract}

Key words: political parties, constitutions, regulation, amendments, Luxembourg

Funding: This work was supported by the Economic and Social Research Council [RES-061-250080] and European Research Council [ERC_Stg07_205660]

Acknowledgements: The author would like to address special thanks for insightful comments on previous versions of this article to Ingrid van Biezen, Kenneth Janda, Neil Mitchel, Donley Studlar, Tim Welsh and Richard Rose. 


\section{Introduction}

Scholars have recently begun to closely examine party regulations in democracies both old and new (see Barnedt, 1998; Janda, 2005; Müller and Sieberer, 2006; Reilly, 2006; Bogaards et al, 2010; van Biezen 2012; Rashkova and van Biezen 2014). In addition to ordinary laws, countries have increasingly sought to regulate political parties by noting them in their constitutions. This article enquires into why constitutions have become a prime agency for regulating political parties. It concentrates on the demand for constitutional regulation of parties by examining the relevant actors involved in the process. Based on insights from the literature on political parties, constitutionalism and on theories of regulation, it explains why parties are included as a constitutional feature in contemporary democracies and what the implications are for political systems.

After the Second World War (WWII), political parties have progressively been regulated by the constitutions of European democracies and recognised in constitutional terms as necessary institutional components of the democratic system. Italy and the Federal Republic of Germany were among the first countries to note political parties in their new constitutions of 1947 and 1949, respectively. These countries' initiative of party constitutionalisation has been followed in waves by the large majority of European democracies. In the majority of postmodern European countries, parties were included in the new constitutions adopted in the post-war, postindependence or post-authoritarian regime period. After the first post-war constitutionalisation of parties, several constitutions were amended to strengthen or expand the role of political parties (Biezen and Borz 2012).

Previous scholarship has focused on how the constitutional regulation of parties is worded (van Biezen, 2012) and analysed the content of European constitutional regulations or discussed the reasons behind the lack of party constitutionalisation in common law countries (Gauja, 2010). This article complements previous research by discussing the question of why countries adopt party constitutional regulation. Little is known regarding the demand for party constitutionalisation, the actors involved in the process and their justifications. These aspects are addressed by this article through an analytical framework of party constitutional regulation in a democratic system. 
This article discusses the case of Luxembourg, which provides valuable insights into the process of party constitutional regulation. Luxembourg is a 'party amendment only' case that offers a better opportunity for analysis (cf. Yin, 2003) in comparison with cases in which the constitutional articles on parties were amended in larger processes of constitutional reform. Until 2008, in addition to the Netherlands, Belgium, Denmark and Ireland, Luxembourg was one of the few countries in Europe that did not mention political parties in their written constitutions. The country's basic law was revised in 2008 solely to introduce a special article on political parties. Political parties in Luxembourg were already subject to regulation via the 1999 ordinary law on the reimbursement of campaign expenses. Furthermore, a constitutional amendment is a timeconsuming and costly procedure that usually requires a qualified majority and the agreement of the actors involved (Rasch and Congleton, 2005; Tsebelis, 2002). Thus, the Luxembourg case is revelatory because it provides an opportunity to analyse those justifications, which solely explain the salience of constitutionalising parties, while it controls for all other intervening influences.

The article proceeds as follows: first, it presents a framework for analysing the constitutional regulation of parties, which bridges theoretical arguments from scholarship on political parties, new constitutionalism and economic regulation. Second, this article illustrates the framework by using the case of Luxembourg and presenting the forces behind the 2008 constitutional revision and their justifications. This article then concludes by assessing the implications of a contemporary constitutional revision on the importance attributed to political parties in contemporary democracies.

\section{General framework for party constitutional regulation}

Party constitutional regulation, whether detailed or symbolic in its content, first and foremost represents the recognition of parties as necessary institutions in the political system. Party constitutional regulation is different from legal party regulation for various reasons. The constitution sets the principles to be followed by ordinary laws, it provides rigidity and stability to parties' acquired legal status, it avoids ad-hoc secondary legislation designed to favour partisan interests (Gauja, 2010), and recently, it adapts and reflects contemporary changes in parties' status from being mainly outside the reach of the state to being in need of state resources (Biezen and Kopecky, 2014). 
The framework advanced in this article illustrates the justifications behind different models of party constitutional regulation (see table 1). It considers the actors involved in the constitutional revision process (parties, national institutions, and external actors) and presents their justifications. It further advances propositions on the relation between justifications and the expected content of constitutional regulation. This framework complements previous scholarship by Renwick (2010) and Nwokora (2014), which discusses competitive, cooperative and ideological strategies in adopting electoral and party finance laws. In contrast to the latter, party constitutional regulation involves a constitutional revision procedure that operates by different rules. There are more incentives for cooperation and cartel behaviour given the need for a qualified majority to pass amendments and more contemporary involvement of international actors.

Although the content of party constitutionalisation has been previously examined from a comparative perspective (see van Biezen and Borz 2012), the framework presented here emphasises the justifications for constitutional regulation. As detailed below, these have been derived following a combination of a deductive approach with cues from new constitutionalism $(\mathrm{j} 1, \mathrm{j} 5, \mathrm{j} 6)$, economic regulation and party theory $(\mathrm{j} 2, \mathrm{j} 3, \mathrm{j} 4)$, with an inductive approach through process tracing. The latter clarified the key actors and steps in the contemporary constitutional revision process.

In addressing the question of why parties are included in the constitutions of democratic states, one needs to acknowledge how ideas regarding constitutions and constitutionalism have changed over time. The old liberal and republican doctrines of constitutionalism assigned three functions to a modern constitution: creation of a political entity, establishment of its fundamental institutional structure, and limitations on the exercise of political power (Murphy, 1993; Castiglione, 1996). With time, as individual rights became more important, constitutions became structures of political legitimation (Sartori, 1994; Bartolini, 2010). This approach emphasises that new constitutionalism should move beyond 'the traditional concern of limiting the exercise of political power' (Elkin, 1993: 21). Its analytical relevance for party constitutionalisation is based on highlighting (1) the membership of citizens in political parties, (2) parties as necessary institutions that contribute to the balance of interests within society and (3) the role of judicial review through constitutional courts. 
First, contemporary constitutionalism focuses on citizenship as a form of responsible membership in institutions, such as states, corporations, unions or political parties, in which membership is regarded as a voluntary association of principals (Elkin, 1993). Subsequently, the practice in contemporary democracies is to delegate the task of representation to political parties.

Constitutions now recognise parties as the agents of citizens, who are the ultimate principals in a democracy. Second, the competition between political parties in elections and in parliament offers a balance of power that creates government accountability to the electorate (Bellamy, 2007). Consequently, representative democracies recognise political parties in their constitutions as institutions that contribute to the balance of interests within society. Third, new constitutionalism emphasises the role of judicial review and of constitutional courts in assessing the constitutional legality of other legal norms and in ensuring that political elites are acting upon democratic principles (Stone Sweet 2000). Therefore, Constitutional Courts can exercise checks on the activity and behaviour of political parties.

What one must consider when discussing contemporary constitutionalism is the influence of external actors on national constitutional practices. When international actors become involved in national politics, constitutional independence is ceded and sovereign equality is transformed. By the end of the $20^{\text {th }}$ century, constitutionalism had already moved beyond the state. The European Union has the need to address recognition of its structures in a constitutional framework (Wiener, 2007). Constitutions consider the policy-making needs of contemporary policies (Elkin, 1993) and recognise that in contemporary democracies, the task of representation is delegated to political parties. From this follows the need to introduce parties in the constitution or have a stipulation regarding further secondary legislation on party finance or party organisation.

Similar to constitutions and constitutionalism, political parties have undergone various stages of development from cadre and mass parties to catch-all and, later, cartel parties that are more and more financially dependent on the state (Katz and Mair, 1995). These parties' constitutional regulation has become progressively more extensive. In terms of content, the models of party constitutional regulation have developed differently in the period since WWII (see van Biezen 2012). Immediately after the war and from the 1970s until late 1989, the emphasis was on parties in public office (government, parliament and their role in elections). After the 1990s, the emphasis changed towards a party constitutional regulation model aimed at defending democracy. It is under this model that the extra-parliamentary party (i.e., conditions and limitations to membership in political parties) is defined by constitutions together with rights and freedoms 
expressed by parties (i.e., freedom of association). However, the constitutional regulation of parties as a special type of public utility in relation to democratic principles has received minimal focus after the war but increased in importance in the 1970s (Portugal) and more recently after 2000 (Switzerland and Luxembourg).

\section{Political actors and their justifications}

To explain why countries adopt party constitutional regulation, this paper analyses the demand for constitutional regulation. This demand may originate from different societal and political actors with different justifications. The actors are expected to be political parties, national institutions or other organisations such as the media or non-governmental organisations (NGOs), local constituents or international organisations.

To understand the need for regulation of political parties by constitutions, one can draw on the economic theory of regulation, which argues that 'as a rule, regulation is acquired by the industry and is designed and operated primarily for its benefits' (Stigler, 1971: 3). Similarly, by applying this logic, it is to be expected that party constitutional regulation will be acquired and designed primarily for the benefit of parties, particularly the incumbents who are the primary actors involved. It is parties that control the process of constitutional revision, and no amendment would pass without their agreement. Parties' interests are related to power, expressed as office, policy or votes (Strøm 1990); however, before such goals are realised, they are also interested in organisational survival. Hence, the parties' justifications strive to meet those interests. From the perspective of parties and of other actors involved, one can identify at least six justifications and benefits of constitutional regulation.

First, the legitimation of parties' institutional agency role (j1) and hence the recognition of their importance as agents of citizens in a democracy. Parties' legitimation as agents provides the acknowledgement of being part of the power structure and provides legal status to the link with voters and with deputies elected on parties' electoral list. Direct recognition in a constitutional article legally validates parties' roles and activities; it further institutionalises the delegation chain from voters to party representatives in the parliament. Direct recognition makes parties' place in the political system entrenched by the country's higher law, which is ultimately more stable and less prone to change in comparison with an ordinary law. 
Second, to ensure organisational survival (j2) and functional local branches throughout the electoral cycle, parties need resources and direct subsidies from the state; this can compensate for declining resources from membership fees. As actors directly involved in the constitutionalisation process, parties can grant themselves advantages. Parties can share an interest in receiving resources from the state. State subsidies will, at least in part, contribute to reducing or preventing financial scandals and corrupt clientelistic practices related to private donations.

The third justification (j3) is the 'elimination' and clear role distinction from possible 'rivals' such as other political groups or associations. Political parties want to protect their role of proffering candidates for election and sending elected representatives to the parliament. In particular, leftist parties, which traditionally had links with trade unions, are expected to emphasise this justification.

The fourth justification (j4) is the gain of control over the entry of other parties into the system to restrict competition, particularly from possible anti-system, undemocratic parties. Various constitutions may ban certain parties such as the fascist party in Italy or Poland, parties that may be a threat to democracy in those states, particularly in countries with an authoritarian past.

Political parties are involved in this regulatory process either individually as an organisation or collectively via state institutions. Demand for constitutional regulation of parties can originate from other non-state actors. From this perspective, one can add other justifications for the constitutional regulation of democratic parties.

[Table 1. about here]

The fifth justification ( $j 5$ ) is related to the place that political parties have acquired in a political system and the need to prevent any misuse of power via special oversight and restrictions. The objective is to protect the democratic system against corrupt activities and to ensure that the behaviour and activities of parties run in accordance with the higher law of the country. Consequently, parties will become more accountable; their activity will be more transparent and more public. Although mainly addressed by state institutions, opposition parties are also expected to resort to this justification. 
The sixth justification (j6) for party constitutional regulation is legal administrative necessity or efficiency gains for all actors involved in the process. Constitutional regulation offers the basis for compliance with secondary legislation on parties and the need for its rigorous application. Additionally, when confronted with various cases that involve political parties, courts will find it easier to make normative and empirical judgements regarding political dynamics and entities, which they can identify and for which they will find legitimacy in the constitution.

The type of justification depends on the political actors involved in the process of constitutional regulation (see table 1). The initiative can originate from any actor; however, the entire process of constitutional regulation can involve all of them. Scandals (corruption, fiscal evasion) may prompt reform, and politicians may not discuss them extensively; in this case, it is the media, NGOs or external actors that may play a proactive role and push the reform forward. The actors' positions will follow national and international legal practices.

Established political parties with or without parliamentary representation can resort to these justifications as single actors (table 1). Partisan institutions such as the parliament and the government are also expected to justify the constitutional legitimation of parties on similar lines as parties themselves, given the entrenchment of parties in the state institutions, but on a collective basis. These institutions' official position is predicted to reflect the position of parties in government more. Other advisory national bodies involved are envisaged to present justifications related to democracy and the appropriate functioning of a political system, such as legitimation, prevention of misuse of power and legal administrative efficiency. The external non-state actors (international organisations, press, and public pressure) involved in the process are more likely to advance the last two justifications because their function is to monitor national democratic standards.

\section{Justifications and constitutionalisation outcomes}

The type(s) of justification brought forward by actors can impact the preferred degree and type of constitutional regulation. The institutional role for democracy can be legitimised via less regulation, whereas preventing misuse of power and administrative efficiency both imply further constitutional stipulations and restrictions on parties' organisation and activities. In terms of 
content, three models of party constitutionalisation have been identified in previous comparative studies of post-war European constitutions: 'public utilities', 'parties in public office' and 'defending democracy' (see van Biezen and Borz 2012). Each model of party constitutionalisation can be linked to more than one justification (see table 1).

How each justification is related to the three models of party constitutionalisation is detailed below and expressed in Propositions 1-3. Proposition 4 explains the evolution of a constitutional amendment from the proposal to the adoption stage. As countries adopt party constitutional regulation tailored mainly around one dominant model (van Biezen 2012), one case can verify one proposition (P1-P3) at a specific point in time. At the most, one case (country) can offer a valid test of propositions across time.

Justifications become dominant when a majority of actors agree on a particular proposal by providing similar motivations to back their position. These motivations are expected to invoke binding constitutional principles (democracy, representation, and rule of law), which are the foundations for each constitutionalisation model and which will subsequently be reflected in the proposed text. Dominant justifications will reveal parties' interests and power status or be the result of particular events such as political scandals or external influence. Contagion from other countries, following certain political events, may play a role in influencing the reform text.

Justifications along the line of democratic institutional legitimation and organisational survival in both old and new democracies are expected to accompany the elite's choice for a proposal that emphasises parties' roles as public utilities. This model of constitutional regulation involves the constitutional definition of key democratic principles such as pluralism, popular will, sovereignty, equality, participation and competition, in terms of political parties. This model also means providing parties with access to public resources in the form of state funding or free broadcasting time on national media. Proposition 1. When justification j1 or j2 is dominant, the constitutionalisation model 'parties as public utilities' will be proposed.

Another choice can be an instrumental constitutional regulation focused on parties in public office. This perspective provides parties with a functional necessity for elections, parliaments and governments and can be found in older established democracies. The public face of parties reflects their electoral role, their activity as parliamentary groups and their governmental capacity. Hence, the justification provided by actors for constitutional regulation is expected to emphasise 
the distinctive representative activity of parties in such institutions in comparison with other groups that can also aggregate and represent interests but without sending their representatives to parliament. Proposition 2. When justification j3 is dominant, the constitutionalisation model 'parties in public office' will be proposed.

Justifications related to the prevention of misuse of power via special oversight and restrictions are expected to be linked to the third model of party constitutional regulation - defending democracy. This outcome identifies parties with fundamental democratic rights and tends to constrain their identity, activity and behaviour to be in accordance with the fundamental values of the democratic constitutional order. Democracy can be protected by regulating the activity and behaviour of parties, their identity and programme, by establishing restrictions to party membership and by maintaining them under judicial oversight. The model is followed mainly by new democracies, and the justifications advanced are expected to be along the lines that preclude any undemocratic elite behaviour. Proposition 3. When justification j4, j5 or j6 is dominant, the constitutionalisation model 'defending democracy' will be proposed.

Usually, constitutional amendment rates decrease as the number of veto players increases, particularly when voters are involved in the process through ratification referendums (Lutz 1994; Rasch and Congleton 2006). Between the proposal and the adoption stage of a constitutional amendment there is an intermediate phase, which involves parliamentary negotiations and vote decisions. Because constitutional amendments are usually adopted with a qualified majority, the adopted proposal will very much depend on the existence of a parliamentary (required) majority, on the number of institutional and partisan veto players and on the level of agreement among political parties. When the number of institutions with veto powers involved in the process of constitutional change increases, the final amendment proposal is likely to encounter several modifications from its initial text. The incumbents' proposals are usually expected to prevail provided that certain conditions are met. Their proposed amendments may involve modifications depending on whether they need additional votes for the required majority in parliament. The content of initial amendments will be subsequently altered to secure sufficient approval. Proposition 4. The adopted constitutional amendments are likely to reflect the incumbent's preferences, particularly when the number of institutional veto players is low.

To illustrate the framework and examine the justifications for constitutional regulation of political parties (whether related to agency legitimation, organisational survival, democratic competition, 
role distinction from rivals, misuse of power or administrative legal necessity) and their link to the outcomes or models of constitutionalisation, the analysis and discussion in the next sections illustrates the process using the Luxembourg case.

\section{Case study: background and empirical strategy}

After several proposals registered from 2001 until 2007, without attracting much media attention, the final text of article 32 bis $^{1}$ marking the constitutionalisation of political parties in Luxembourg entered into force in March 2008 and reads as follows: 'Parties or political groups express democratic pluralism. They contribute to the formation of popular will and the expression of universal suffrage. They form and freely exercise their activity under the respect of the Constitution and the law'. The full text of all proposals is presented in the Online Appendix, table 2.

The country's constitutional revision procedure requires amendments to be adopted by the Chamber of Deputies during the same term, in two successive votes, separated by an interval of at least three months (Schmit, 2009), each with at least two-thirds of its members of Parliament (MPs). Another national actor involved is the advisory Council of State, which is perceived as a substitute for a second chamber and has 21 politically affiliated members appointed for 15 years. The Council can suggest adaptations and modifications to bills and proposals (Dumont and De Winter, 2003), and if it chooses not to exempt the Chamber from the second vote, it can delay the adoption of bills by at least three months (Dumont and Poirier, 2007). Every five years, 60 MPs are elected to the Chamber by a system of proportional representation with open lists. In a system with six parliamentary parties since 1999, the dominant parties are the Socialist Party (LSAP) and the Christian Social People's Party (CSV). These parties governed together at the time of the amendment, and outside that period, they seldom formed different governing coalitions with either the Democratic Party (DP) or the GRÉNG (Greens).

The most relevant international actors for the constitutional regulation of parties were the Council of Europe via the Group of States against Corruption (GRECO) and the Venice Commission, an advisory body to the European Council that provides legal advice to countries on laws that are important to the democratic functioning of institutions. 
In terms of methodology, this study is based on the content analysis of documents that are advanced in the process of constitutional revision from the proposal to the adoption stage. These documents were scrutinised for reasons each actor provided in favour or against various proposals. The inherent limitation of analysing formal documents and recorded debates is the inability to unveil interests that are unlikely to be publicly admitted. Interviews with the political elite (the LSAP party leader, the chair of the institutional reforms committee, the president of the Council of State, and one member of the Parliamentary Constitutional Commission) were used to identify the stages in the process and as a validity check on actors' justifications. The documents for analysis were selected based on a process tracing strategy that followed the legal steps in the constitutional revision procedure (see Online Appendix for details). Each party, parliamentary commission and institution involved in the process was required to present an official position paper on the constitutional amendment. The content of amendments was analysed by codifying the legal text in accordance with established methods (see van Biezen and Borz 2012), whereas the justifications of this framework were identified in the actors' motivations from position papers, reports, debates or interviews. Detailed examples of justifications are presented in the Online Appendix, Table 1.

\section{Why include parties in the constitution of Luxembourg: justifications and outcomes}

\section{The 2001 amendment proposal}

The 2001 proposal was advanced by socialist opposition MP Asselborn and verifies Proposition 1. The proposal was similar to article 32bis adopted in 2007 but with an additional sentence on the need for parties to respect the constitution and hence the need for their further regulation and judicial oversight. The constitutionalisation model, which transpired from the 2001 text (table 2 Online Appendix), is parties as public utilities because parties were associated mainly with democratic principles such as pluralism, popular will, and universal suffrage.

The dominant justification behind the need for a constitutional regulation was agency legitimation (j1). During the Constitutional Commission meeting (Chambre des Députés, 2001: 6), politicians across all parliamentary groups emphasised the necessity of regulating parties and the importance of stipulating in the constitution that they are 'essential instruments' in a democracy. The individual positions of party groups occurred later in 2002, when the Greens emphasised the need to recognise parties as the 'expression of a democratic process of political decision making' (Chambre des Députés, 2002a:2). Similarly, the parties' constitutional regulation was supported 
by the ADR (Action Committee for Democracy and Social Justice) because, as organisational structures, parties have become 'imperative for expressing the popular will and for gaining the popular vote' (Chambre des Députés 2002c: 2).

To simplify the article while taking inspiration from the French constitution, article $4^{2}$, the Commission of Institutions and Constitutional Revision, made changes to the 2001 text and replaced 'respect for constitution and the law' with 'respect for democratic principles' (Chambre des Députés, 2001). With the exception of one incumbent party, CSV (Chambre des Députés, 2003a), no party group completely agreed with the main text of the amendment; therefore, no text was proffered for discussion in the Chamber and no other institutional actor became involved in the process.

To distinguish themselves from other political 'rivals' (j3), in 2002, the Socialist opposition group (LSAP), in their written position, recommended avoiding the placement of political parties and political groups at the same level of legal importance and suggested the constitutional text be limited to political parties only (Chambre des Députés, 2002b). Similarly, the other much smaller opposition party, ADR, demanded more clarity to avoid interpretations according to which political groups can develop into political parties and vice versa (Chambre des Députés 2002c). The Greens, also in opposition until 2013, requested the specification of a secondary law on political parties to be noted in the constitutional text and emphasised that due to party finance scandals from the 1980s and 1990s, the control of parties' status and activity has become a legal necessity (j6) (Chambre de Députés, 2002a,c). Subsequently, the other incumbent, the Democratic Party (DP), acknowledged the 2001 proposal as raising the problem of clarifying the legal status of political parties and political groups (Chambre des Députés, 2003b).

\section{The 2002 amendment proposal}

Demanding more regulation, the small opposition parliamentary group of ADR did not provide its accord to the 2001 proposal; instead, it proposed another text, which would also include respect for 'the principle of national sovereignty'. If adopted in the 2002 format (see table 2 Online Appendix), the dominant model of party constitutionalisation would have been the defending democracy model, which sets restrictions on parties' activity and behaviour and assigns them to the judicial oversight procedure. This proposal had, as prevalent justification, preventing the misuse of power (j5) and verifies Proposition 3. According to ADR, parties and democracies currently 'have become inseparable' and are hence 'obliged to develop a social global vision 
which equally integrates diverse interests' (Chambre des Députés, 2002c: 2). The ADR equally stressed that both parties and political groups should be guaranteed similar rights by the constitution. Given that this proposal resembled the 2001 proposal, which raised wide criticism, it has not received further consideration from the Commission.

\section{The 2004 proposals}

An extensive proposal for constitutional revision was proffered in 2004 by the incumbent MP (DP) Rippinger (table 2 Online Appendix). The text is composed of a long article 26bis (which included separate provisions on the status, organisation, activity and finance of parties) and a revised article 95 in which the Constitutional Court gains the power of checking the conformity of a political party with the constitution. The exposition of motives by the DP, stipulates that 'In fact, Luxembourg is not protected from extremist parties that could threaten democracy and fundamental rights' (Chambre des Députés, 2004b: 3). This proposal follows the defending democracy model of constitutional regulation and verifies Proposition 3.

Restricting competition from anti-system parties (j4) has emerged as one of the main justifications behind the 2004 proposal. During the February 2004 session of the Constitutional Commission, the debates essentially stressed the need to avoid any possible competition from or legitimation of extremist parties. The Greens also emphasised that a clear and detailed regulation will avoid any abuse of power (j5). With the exception of the Greens, all parties rejected the idea of excessively controlling the activity of parties during the 2004 parliamentary debates (Chambre des Députés, 2004a). The argument was related to the 1937 historical events, when a law on disbanding the Communist Party or of any other violent groups or associations was subjected to a referendum and failed to gain popular support. The Socialist Party wanted to avoid the repeat of such an event in which citizens opposed the initiative of political parties. Consequently, the party's MP Asselborn proffered in 2004 his previous 2001 proposal, which as discussed, verifies Proposition 1. This time, the proposal was shorter in length (table 2 Online Appendix) and more in line with the coalition partner, CSV preference for a concise constitutionalisation. To facilitate agreement on a final text, the Commission instituted a working group across all parties, and the issue returned on the Commission's agenda in 2007.

\section{The 2007 proposal}

The 2007 amendment proposal by incumbent LSAP Asselborn can be assigned to a constitutionalisation model that portrays parties as public utilities, and the justifications outlined 
below provide support for Proposition 1. Political parties and each national institution involved in the constitutional revision process expressed a position with regard to this proposal. With the Government, the Chamber of Deputies and the Council of State, as detailed below, each emphasised the need for democratic institutional legitimation (j1) as the prevalent justification in their official position papers. Specifically, these actors referred to the need for a legal acknowledgment of parties' status in a democracy, the recognition of their entrenchment in state institutions and the legal institutional link to their MPs.

The need for democratic institutional legitimation following the development of parties was openly acknowledged by the incumbent CSV politicians during the 2007 parliamentary debates: 'Today $[. .$.$] we have a different approach to parties, because today we also recognize the$ important activities of parties, because we are also prepared to strengthen the parties, $[\ldots]$ and also to recognize in the Constitution the role they fulfil in reality' (Chambre des Députés 2007d: 3). The legitimation of parties' role in a democracy is obtained via their official recognition. The positions advanced during debates legitimated parties by emphasising various steps in the chain of delegation. Parties are the link between voters and the politicians who are elected; this is also emphasised by the opposition Green MPs. 'If parties did not exist and there were only candidate lists, this would end up in limiting the link between the voters and the people they voted for [...]. But that is not the case because there are political structures [parties] in which all citizens can be involved' (Chambre des Députés 2007d: 5). Citizens rely on political parties to articulate and aggregate their interests, and parties are the intermediaries in the chain of delegation. Consequently, according to constitutional experts, article 32bis 2008 signifies the 'institutional legitimation' of political parties and the establishment of a formal linkage with 'their' deputies (Schmit, 2009: 176). Additionally, the Council of State emphasised parties' particular task of selecting and presenting candidates for elections, which allows for the expression of universal suffrage and ultimately the exercise of a mandate in public institutions (Chambre des Députés 2007b). Although the mandate and parliamentary activity of MPs were previously regulated separately by the constitution, they were formally related as of 2008 .

During the 2007 parliamentary debates, most party groups appealed for an official acknowledgement of their role and activities, which contribute to the stability and continuity of democratic institutions. Incumbent MPs from CSV agree with the LSAP deputies who declare that pluralism and political parties' activities are essential elements of democracy: 'Without them 
a parliamentary democracy cannot function in the long run, but it is also equally clear that a democracy does not function entirely through political parties' (Chambre des Députés 2007d: 1).

The government, in its official position, recognised parties as being essential elements for the appropriate functioning of Luxembourg's democratic parliamentary regime and favoured the revision (Chambre des Députés, 2007a). Although the Council of State did not initially view the necessity of including parties in the constitution (before 2008, their status was associations as per art. 26 of the constitution), it did ultimately stress the essential democratic role of political parties as justification for constitutional status. As stipulated by the Council (Chambre des Députés, 2007b), the agents were already performing functions recognised as essential for democracy, and they needed to be credited for their activity.

Secondary justifications that transpired that year referred to prevention of abuse of power (j5) and administrative necessity (j6). The Council of State official reaction made reference to checks on monopoly and misuse of power (j5) by political parties. Notwithstanding that in 2007, the Council recommended a short version of the article without much legal restraint on parties, they further advised caution on the usage of terms such as 'express' vs 'contribute to the expression' so that political parties could not be understood as the sole agents that express democratic pluralism (Chambre des Députés 2007b). Trade unions and associations can perform a similar function. However, the suggestions of the Council of State were not considered necessary to be implemented by the Parliamentary Commission.

From the international actors, it was no surprise that GRECO's (2008) reactions in its country evaluation report emphasised the issue of transparency in political financing and that of conflicts of interest involving elected representatives (j5). GRECO expresses positions on any type of abuse of power that can undermine fundamental civil and political rights, such as the right of expression, association and the right to free elections, all of which are partly implemented through the activity of political parties. The Venice Commission did welcome the placement of political parties at a constitutional level and raised the question of whether the provision could be interpreted as a monopoly of political parties (Venice Commission, 2009).

The international actors also stressed the administrative necessity (j6) of party constitutional regulation. This justification implies a clear definition of parties as legal entities with transparent activities. As a full member of GRECO, Luxembourg participates without restrictions in mutual 
evaluation procedures. As the interviews conducted suggest, in an indirect manner, GRECO's recommendations have prompted the constitutional revision. The Council of State reaction for immediate action in defining the status of political parties in the constitution before the adoption of a finance law was, in part, influenced by GRECO's recommendations ${ }^{3}$. Since 2001, in its evaluation reports on the transparency of political funding in Luxembourg, the group also addressed the lack of legal definitions of political parties and later welcomed the Chamber's decision to consider a constitutional revision that was meant to incorporate political parties (GRECO, 2008). The group's legal input was seconded by the Venice Commission. The Commission noticed the absence of a clear definition of political parties and noted its necessity: 'Owing to the importance given to political parties by the Constitution, it would be useful to define them in this memorandum with reference to any relevant law(s), if not in the Constitution' (Venice Commission, 2009: 5).

\section{Explaining the adoption and wording of the 2007 proposal}

Following the favourable position taken by all national actors, the 2007 proposal was discussed and voted in the Chamber in December of the same year (Chambre des Députés 2007c). Proposition 4 stipulates that the adopted amendment, in its final text, will favour the incumbents' position if the number of institutional veto players is low. The number of institutional veto players increases with each institutional authority beyond parliament, institutions that must agree to the proposed amendment. Luxembourg had none of the veto players who could be included in this category such as bicameralism, presidentialism, federalism or mandatory referendum requirements for validation. Thought to act as a secondary chamber, the Council of State only has advisory powers and cannot be regarded as a full-fledged veto player with a strong influence in the adoption of an amendment; certain recommendations from the Council were not considered.

The reduced number of institutional veto players and the parliamentary strength made it very easy for incumbent parties in 2007 to achieve consensus for their favoured proposal. Between 2004 and 2009, the government was formed by the LSAP and CSV, who were short of two MPs to achieve the qualified majority needed to pass the constitutional amendment. As shown in table 2 Online Appendix, the successful proposal, which the Parliament adopted, originated from the governing party. Opposition parties were consistently in favour of more extensive regulation but, once in government (LSAP), also ready to accommodate the preferences of their coalition partner 
(CSV) to achieve the required qualified majority in the Chamber (see LSAP proposals from 2001 until 2007, table 2 Online Appendix).

Early proposals by opposition parties triggered criticism from the coalitions' partisan veto players. The 2001 proposal by LSAP, then an opposition party, did not achieve consensus because parties assigned high importance to their freedom of activity. A certain control by the Constitutional Court would have been against the current political practices in Luxembourg (Chambre des Députés 2007d). The Greens and CSV protested against constitutional control on the status and activities of political parties on the grounds that the Court exercises control solely over laws and treaties. Moreover, given the absence of an authoritarian past, there was no need for a stronger constitutional court. Similarly, the 2002 and 2004 proposals by opposition parties ADR and DP encountered resistance from the incumbents partly for stipulating excessive restrictions and were not provided to the plenary session by the parliamentary Commission. Consequently, to achieve consensus, the subsequent 2007 proposal by incumbent Asselborn (LSAP) was shorter in length (Chambre des Députés, 2004b) and very much in accordance with the final text adopted (see table 2 Online Appendix).

Another explanatory factor for why previous proposals were not endorsed, is the constitutional revision procedure, which, until December 2003, involved the automatic 'dissolution' of the Chamber (art 114 of the Constitution) once the legislature declares the need for revision. This explains why early proposals were advanced by opposition parties with hopes of winning the elections following the process of dissolution. The new procedure (see Online Appendix), which follows from the process of European integration, is less rigid, requires votes during the same legislative term and overall provides more incentives for consensus across parties.

\section{Conclusion and implications}

This article addressed the question of why contemporary constitutions regulate political parties. It introduced a framework for analysis that consists of actors involved in the process, their interests and justifications. Although the outcome of regulation conveys 'public' goods, parties also want 'private' benefits from regulation: acknowledgement, subsidies, restriction of competition from anti-system parties, role distinction from 'rivals', and guarantees against any misuse of power. 
Empirically, to illustrate the framework, this article considered the case of Luxembourg, which provides a window into the process of constitutional regulation of parties. The empirical evidence illustrates the interplay between political parties, national institutions and international actors and their various justifications for party constitutional regulation. The analysis of the actual outcome of party constitutionalisation in 2008 provided valid support for Proposition 1, whereas the earlier, unadopted proposals of the opposition provide support for Proposition 3. The constitutional justification of parties as public utilities has prevailed over the need to extensively regulate them to defend democracy as the opposition would have preferred.

The propositions outlined in the framework depict alternative paths for future processes of party constitutional regulation in countries without parties in their constitutions or paths for amending previous constitutional provisions. In Hungary, for example, the 2011 constitutional amendments included the removal of a previous art. 3(3) according to which 'no single party may exercise exclusive control of a government body' (Party law in modern Europe, 2014). This change towards removing restrictions was clearly in accordance with the interests of the governing party FIDESZ, which had a qualified majority in the parliament at the time. More comparative research is needed to test all four propositions advanced in this paper.

First, the implications of the contemporary constitutional regulation of parties are related to the increased importance and recognition of parties as indispensable agents of democracy as stated by Schattschneider (1942). Second, the constitutional regulation notes the transformation of political parties and their entrenchment in state institutions. Third, the constitutionalisation is increasingly under the influence of external forces, which suggests that, to a certain degree, contemporary constitutionalism does indeed extend beyond the state. Constitutionalisation considers international practices and can respond to the necessities of the state, as well as to the necessities of the national and international political actors. 
Notes:

1 'bis', from Latin 'second/double', simply places the amendment between article 32 and article 33 of the existing constitution.

2 Article 4 of the current French constitution has a similar text with the adopted amendment. For details, see Party Law in Modern Europe Project Database.

3 As recorded by the author's interview with a member of the Council of State, Luxembourg, February 2010. 


\section{References}

Barnedt, Eric (1998) An Introduction to Constitutional Law. Oxford: Oxford University Press.

Bartolini, Stefano (2010) Taking "Constitutionalism" and 'Legitimacy” seriously. In: Andrew Glencross and Alexander H Trechsel (eds.) EU Federalism and Constitutionalism. The Legacy of Altiero Spinelli. Plymouth: Lexington Books.

Bellamy, Richard (2007) Political Constitutionalism. A Republican Defence of the Constitutionality of Democracy. Cambridge: Cambridge University Press.

Bogaards, Matthijs, Matthias Basedau, Christof Hartmann (2010) Ethnic party band in Africa: an introduction. Democratization 17(4): 599-617.

Castiglione, Dario (1996) The Political Theory of the Constitution. Political Studies XLIV, 417-435.

Chambre des Députés (2001) P.V.IR2. Commission des Institutions et de la Revision Constitutionnelle. Proces Verbal de la reunion du 14 Novembre. Luxembourg. Chambre des Députés (2002a) E0758. Dei Greng. 'Prise de position concernant l'insciption des parties ou groupements politiques dans la Constitution'. Luxembourg.

Chambre des Députés (2002b) E0708. Group Parlementaire Socialiste. 'Inscription des parties politiques dans la Constitution'. 15 Janvier. Luxembourg.

Chambre des Députés (2002c) E0876. Group Parlementaire ADR. Prise de position du group parlementaire ADR concernant l'inscription des parties ou groupement politiques dans la Constitution. 8 Fevrier. Luxembourg.

Chambre des Députés (2003a) E8970/c. Group Parlementaire CSV. 24 Avril. Luxembourg. Chambre des Députés (2003b) E8978. Group Parlementaire DP. 29 Avril. Luxembourg. Chambre des Députés (2004a) Commission des Institutions et de la Revision Constitutionele. Proces Verbal de la reunion du 18 Fevrier. Luxembourg.

Chambre des Députés (2004b) 5284 Proposition de revision portant introduction de L'article 26bis de la Constitution et portant modification de l'article 95ter de la Constitution.

Chambre des Députés (2005) PV. IR 11. Commission des Institutions et de la Revision Constitutionnele. Proces Verbal de la reunion du 9 Mars. Luxembourg. Chambre des Députés (2007a) $5673^{1}$. Prise de position du government. 31 Juillet. Luxembourg.

Chambre des Députés (2007b) 5673² Avis du Conseil D'Etat. 6 November. Luxembourg. Chambre des Députés (2007c) $5673^{3}$ Rapport de la Commission des Institutions et de la Revision Constitutionelle. 21 Novembre. Luxembourg. 
Chambre des Députés (2007d) Report of the Commission on Institutions and Constitutional Revision. 4.5676 Proposal for revision regarding the creation of a new article 32(a) in the Constitutions. Chamber of deputies, 5 December, Luxembourg.

Dumont, Patrick and De Winter, Lieven (2003) Luxembourg: A case of more 'direct' delegation and accountability. In: Strøm K and Bergman T (eds.) Delegation and Accountability in parliamentary democracies. Oxford: Oxford University Press.

Dumont, Patrick and Philippe Poirier (2007) Luxembourg. European Journal of Political Research 46(7-8): 1132-1037.

Elkin, Stephen (1993) Constitutionalism's successor. In Elkin, Stephen and Edward K Sołtan, (eds.) A New Constitutionalism: Designing Political Institutions for a Good Society. Chicago: Chicago University Press.

Gauja, Anika (2010) Political Parties and Elections: Legislating for Representative Democracy. London: Ashgate.

GRECO (2008) Third Evaluation Round Evaluation Report on Luxembourg on the Transparency of Political Party Funding. Greco Eval III Rep (2007) 6E. 13 June. Strasbourg.

Janda, Kenneth (2005) Adopting Party Law. In: Political Parties and Democracy in Theoretical and Practical Perspectives. Washington, DC: National Democratic Institute for International Affairs.

Katz, Richard S. and Mair, Peter (1995) Changing Models of Party Organization and Party Democracy: The Emergence of the Cartel Party. Party Politics 1(1): 5-28.

Lutz, Donald S. (1994) Towards a Theory of Constitutional Amendment. American Political Science Review 88: 355-70.

Müller, Wolfgang C. and Ulrich Sieberer (2006) Party Law. In: Richard S. Katz and William Crotty (eds.) Handbook of Party Politics. London: SAGE Publications, pp. 435-445. Murphy, FW (1993) Constitutions, Constitutionalism and Democracy. In: Greenberg D et al (eds.) Constitutionalism and Democracy: Transitions in the Contemporary World. Oxford: Oxford University Press.

Nwokora, Zim (2014) The distinctive politics of campaign finance reform. Party Politics 20(6) 918-929.

Party Law in Modern Europe Database (2014) http://www.partylaw.leidenuniv.nl/party-law, accessed October 2014. 
Rashkova, Ecaterina R. and Ingrid van Biezen (2014) The legal regulation of political parties: Contesting or promoting legitimacy? International Political Science Review (35): 265 274.

Rasch, E. Bjørn and Rogert D. Congleton (eds.) (2006) Democratic Constitutional Design and Public Policy: Analysis and Evidence. Cambridge: The MIT Press.

Reilly, Ben (2006) Political Engineering and Party Politics in Conflict-Prone Societies. Democratization 13(5): 811-827.

Renwick, Alan (2010) The Politics of Electoral Reform. Cambridge: Cambridge University Press.

Sartori, Giovanni (1994) Comparative Constitutional Engineering. New York: New York University Press.

Schmit, Paul (2009) Precis de droit constitutionnel. Commentaire de la constitution luxembourgeoise. Luxembourg: Editions Saint Paul.

Schattschneider, E.E. (1942) Party Government. New York: Holt, Rinehart and Winston.

Stigler, George J. (1971) The Theory of Economic Regulation. Bell Journal of Economics 2(1): 3-21.

Stone Sweet, Alec (2000) Governing with Judges: Constitutional Politics in Europe. Oxford: Oxford University Press.

Tsebelis, George (2002) Veto players: How Political Institutions Work. Princeton: Princeton University Press.

Van Biezen, Ingrid (2012) Constitutionalizing Party Democracy: The Constitutive Codification of Political Parties in Post-War Europe. British Journal of Political Science 42(1):187-212.

Van Biezen, Ingrid and Gabriela Borz (2012) Models of Party Democracy: Patterns of Party Regulation in Post-War European Constitutions European Political Science Review 4(3): 327-359.

Van Biezen, Ingrid and Petr Kopecky (2014) The cartel party and the state: Party-state linkages in European democracies. Party Politics 20(2): 170-182.

Venice Commission (2009) Interim opinion on the draft constitutional amendments of Luxembourg. CDL-AD(2009)057. 14 December. Venice.

Wiener, Antje (2007) Contested Meanings of Norms: The Challenge of Democratic Governance beyond the State. Comparative European Politics 5(1): 1-17

Yin K., Robert (2003) Case Study Research. Design and Methods. Thousand Oaks: Sage Publications. 


\section{TABLES}

Table 1. General framework of constitutional regulation of political parties

\begin{tabular}{|c|c|c|c|c|c|c|c|}
\hline Justification & & $\begin{array}{l}\text { Agency } \\
\text { Legitimation } \\
(\mathrm{j} 1)\end{array}$ & $\begin{array}{l}\text { Organizational } \\
\text { survival } \\
\text { (j2) }\end{array}$ & $\begin{array}{l}\text { Role distinction } \\
\text { from 'rivals' } \\
\text { (j3) }\end{array}$ & $\begin{array}{l}\text { Restrict } \\
\text { competition } \\
\text { to democratic } \\
\text { parties (j4) }\end{array}$ & $\begin{array}{l}\text { Prevent misuse } \\
\text { of power } \\
\text { (j5) }\end{array}$ & $\begin{array}{l}\text { Administrative } \\
\text { legal } \\
\text { necessity } \\
\text { (j6) }\end{array}$ \\
\hline \multirow{3}{*}{$\begin{array}{l}\text { Positions of } \\
\text { political } \\
\text { actors }\end{array}$} & $\begin{array}{l}\text { Individual } \\
\text { (parties) }\end{array}$ & Yes & Yes & Yes & Yes & Yes & Yes \\
\hline & $\begin{array}{l}\text { Collective } \\
\text { (National } \\
\text { institutions) } \\
\end{array}$ & Yes & No & Yes & No & Yes & Yes \\
\hline & $\begin{array}{l}\text { External } \\
\text { (non-state) }\end{array}$ & Yes & No & No & No & Yes & Yes \\
\hline $\begin{array}{l}\text { model of } \\
\text { constitutional } \\
\text { regulation }\end{array}$ & & \multicolumn{2}{|c|}{ Public utilities } & Public Office & \multicolumn{3}{|c|}{ Defending democracy } \\
\hline Proposition & & \multicolumn{2}{|l|}{ Proposition 1} & Proposition 2 & \multicolumn{3}{|c|}{ Proposition 3} \\
\hline
\end{tabular}




\section{Online Appendix}

Whilst the real interests of parties cannot be entirely gauged through interviews and the examination of parliamentary debates, the analysis presented in this paper rests with the justifications brought forward by all actors involved in the process of amending the constitution. Specific justifications were identified in official institutional responses to proposals of revision (see table 1). These responses were issued by individual and collective national and international actors, in the parliamentary debates specially organised for this purpose. Generally, they took the form of position papers/opinions. Additionally, they were cross validated by face to face interviews with Luxembourgish political elite.

The process of constitutional revision is led by the Commission on Institutions and Constitutional Affairs (Gerkrath 2013), whose members represent all party groups. Their discussions are influenced by the position paper of the government and the advisory opinion of the Council of State and the Venice Commission. Since 2003, the Commission brings the proposal into the plenary session of the Chamber where modifications to the constitution are agreed by two-thirds majority.

Table 1. Examples of justifications

\begin{tabular}{|c|c|}
\hline $\begin{array}{l}\text { Type } \\
\text { justification }\end{array}$ & Example of actor's position \\
\hline $\begin{array}{l}\text { Agency } \\
\text { legitimation }\end{array}$ & $\begin{array}{l}\text { 'If parties did not exist and there were only candidate lists, this would end up in } \\
\text { limiting the link between the voters and the people they voted for.' (Braz 2007: 4) } \\
\text { 'The institutional legitimation that political parties can acquire with article 32bis, will } \\
\text { permit them to influence and to establish a formal linkage with their' } \\
\text { deputies.'(Schmit, 2009: 177) }\end{array}$ \\
\hline $\begin{array}{l}\text { Organizational } \\
\text { survival }\end{array}$ & $\begin{array}{l}\text { 'Considering the crucial role parties and political groups play in the formation and } \\
\text { expression of popular will, their financing needs to be assured essentially through } \\
\text { public means.' (Chambre des Deputes, 2002c: } 1 \text { ) } \\
\text { 'In the absence of public finance, political parties can hardly cover their expenses } \\
\text { from cotizations, one cannot increase the cotizations without risking to exclude the } \\
\text { least fortunate members.'(Conseil d'Etat 2007) }\end{array}$ \\
\hline Role distinction & $\begin{array}{l}\text { 'Nevertheless, and this differentiates political parties from other organizations, they } \\
\text { do play an important role in our system of institutions'. (Bodry, 2007: 1) } \\
\text { 'One has to avoid placing political groups at the same level of importance as political } \\
\text { parties.' (Chambre des Deputes, 2002b: 1) }\end{array}$ \\
\hline $\begin{array}{l}\text { Restrict } \\
\text { competition from } \\
\text { anti-democratic } \\
\text { parties }\end{array}$ & $\begin{array}{l}\text { 'Mr Asselborn stipulates that Constitutions which mention political parties should } \\
\text { include a stipulation requiring their internal structure and functioning must be } \\
\text { democratic' (Chambre des Deputes 2001: 3) } \\
\text { 'If the 'Constitution guarantees the freedoms of parties and political groups', such } \\
\text { disposition can also legitimate extremist parties...the revision can eventually say that } \\
\text { parties and groups are the expression of democratic pluralism"' (Chambre des } \\
\text { Deputes 2004a: 5) }\end{array}$ \\
\hline $\begin{array}{l}\text { Prevent misuse of } \\
\text { power }\end{array}$ & $\begin{array}{l}\text { 'If political parties are free to form and function, they must respect the Constitution } \\
\text { and the laws'(Chambre des Deputes 2004b: 2) } \\
\text { 'One cannot exclude the possibility of a political party to undertake a radical reform, } \\
\text { as long as it is completed while respecting democratic principles.'(Chambre des } \\
\text { Deputes 2001:2) }\end{array}$ \\
\hline $\begin{array}{l}\text { Administrative } \\
\text { legal necessity }\end{array}$ & $\begin{array}{l}\text { '...the inclusion of political parties in the Constitution is linked with other juridical } \\
\text { questions such as the juridical status of political parties and political groups, the } \\
\text { required criteria for being recognized as parties or political groups, or for example the } \\
\text { juridical responsibilities of members and representatives of parties and political } \\
\text { groups...'(Chambre des Deputes } 2003: 1 \text { ) }\end{array}$ \\
\hline
\end{tabular}


Table 2. Constitutional amendment proposals in Luxembourg

\begin{tabular}{|c|c|c|c|c|c|}
\hline Proponent & \multicolumn{2}{|l|}{ OPPOSITION PARTIES } & \multicolumn{3}{|l|}{ GOVERNING PARTIES } \\
\hline $\begin{array}{l}\text { Wording of } \\
\text { proposals }^{\mathrm{a}}\end{array}$ & $\begin{array}{l}\text { 'Parties or political groups } \\
\text { express democratic pluralism. } \\
\text { They contribute to the formation } \\
\text { of popular will and the } \\
\text { expression of universal suffrage. } \\
\text { They form and freely exercise } \\
\text { their activity under the respect } \\
\text { of the Constitution and the law'. } \\
\text { (2001 Asselborn, LSAP } \\
\text { proposal, not adopted) }\end{array}$ & $\begin{array}{l}\text { 'Parties and political } \\
\text { groups contribute to the } \\
\text { formation of popular will } \\
\text { and to its expression } \\
\text { through universal } \\
\text { suffrage. They form and } \\
\text { exercise their activity } \\
\text { freely. They have to } \\
\text { respect the principle of } \\
\text { national sovereignty and } \\
\text { democracy.' } \\
\text { (2002 ADR proposal, not } \\
\text { adopted) }\end{array}$ & $\begin{array}{l}\text { 'Political Parties and political } \\
\text { groups express democratic } \\
\text { pluralism and contribute to the } \\
\text { formation of popular will and are a } \\
\text { fundamental instrument of political } \\
\text { participation. They form and act } \\
\text { freely under the respect of the } \\
\text { constitution and the law. Their } \\
\text { internal structure and functioning } \\
\text { should be democratic. The statute, } \\
\text { organisation and finance of } \\
\text { political parties are regulated by } \\
\text { law.' (2004 Rippinger, DP } \\
\text { proposal, not adopted) }\end{array}$ & $\begin{array}{l}\text { 'Political parties and } \\
\text { political groups } \\
\text { express democratic } \\
\text { pluralism and } \\
\text { contribute to the } \\
\text { formation of popular } \\
\text { will and to the } \\
\text { expression of } \\
\text { universal suffrage'. } \\
\text { (2004 Asselborn, } \\
\text { LSAP proposal, not } \\
\text { adopted) }\end{array}$ & $\begin{array}{l}\text { 'Political parties } \\
\text { contribute to the } \\
\text { formation of the } \\
\text { popular will and the } \\
\text { expression of } \\
\text { universal suffrage. } \\
\text { They express } \\
\text { democratic } \\
\text { pluralism'. (2007 } \\
\text { Asselborn, LSAP } \\
\text { proposal adopted) }\end{array}$ \\
\hline $\begin{array}{l}\text { Dominant } \\
\text { Justifications }\end{array}$ & Agency legitimation & Prevent misuse of power & Prevent misuse of power & Agency legitimation & Agency legitimation \\
\hline $\begin{array}{l}\text { Model of } \\
\text { constitutionalization }^{\mathrm{b}}\end{array}$ & $\begin{array}{l}\text { Parties as Public utilities } \\
\text { (Proposition1) }\end{array}$ & $\begin{array}{l}\text { Defending democracy } \\
\text { (Proposition 3) }\end{array}$ & $\begin{array}{l}\text { Defending democracy } \\
\text { (Proposition3) }\end{array}$ & $\begin{array}{l}\text { Parties as Public } \\
\text { utilities } \\
\text { (Proposition1) }\end{array}$ & $\begin{array}{l}\text { Parties as Public } \\
\text { utilities } \\
\text { (Proposition1) }\end{array}$ \\
\hline
\end{tabular}

Source: a. Chambre des Deputes (2001, 2002b, 2004b, 2007c); b. each proposal was associated with a constitutionalization model following the content analysis coding procedure used by the Party Law in Modern Europe Project (2014); 
Reference:

Gerkrath, Jörg (2013) Some Remarks on the Pending Constitutional Change in the Grand Duchy of Luxembourgh. European Public Law 19(3): 449-460. 